\title{
Ants response to mining prospection disturbances across vegetation zones in tropical mountain chains of Mount Nimba, Guinea, West Africa
}

\author{
Kolo YEO, Lombart Mesmer Maurice KOUAKOU*, \\ Martine Kah TOUAO Epouse GAUZE, Kaly OUATTARA and \\ Angèle Nicodenin SORO \\ Université Nangui Abrogoua, 02 Bp 801 Abidjan 02, Centre de Recherche en Ecologie, Station d'Ecologie de \\ Lamto, Abidjan, Côte d'Ivoire. \\ ${ }^{*}$ Corresponding author; E-mail: lom-bart@outlook.fr
}

\section{ACKNOWLEDGMENTS}

This study was supported by funding of "Société des Minerais de Fer de Guinée (SMFG)" throughout an environmental impact study.

\begin{abstract}
Even though ants have been successfully used as biological indicators of mine site rehabilitation, studies focused on these insects during the early mining prospecting activities are rare. We conducted a snapshot study with the aim to provide data on possible rehabilitation success in mining sites after disturbances using ant as biological indicators. In this sense, we compared ant richness and species composition across three distinct vegetation zones (Highland meadows, transition savannahs and altitudinal forests) at six mining prospecting sites (Mining Area) and compared them with those of six nearby without mining activities (World heritage Site), all located in the Mount Nimba Strict Nature Reserve. Ants were sampled using pitfall traps and tuna lures. A total of 119 ant species and morphospecies ranged from 95 species at World Heritage Site to 69 species genera were recorded. Ant richness and species composition did not differ significantly among Meadows and Savannah habitats of both study sites, while there was a significant difference among forest habitats. The comparison of weather and soil variables showed only a significant difference for soil $\mathrm{pH}$ among surveyed sites. We found that weather and soil variables did not play a significant role in the segregation of ant assemblage, thus, suggesting that the structure of vegetation result in changes of ant assemblage, and consequently, future restoration action should be focused on the protection and rehabilitation of native forest.

(C) 2019 International Formulae Group. All rights reserved
\end{abstract}

Keywords: Ant communities, mining, rehabilitation, Mount Nimba Strict Nature Reserve.

\section{INTRODUCTION}

Biodiversity is defined as the variety of life forms at all levels of biological organisation, including taxonomic, genetic and ecosystem diversity (Gaston and Spicer, 2004). For biodiversity conservation and sustainable management, our understanding of how habitat features influence species distribution is essential for determining rehabilitation strategies, specifically in natural ecosystems under pressures. Mountain ecosystems are known to be a well-organised natural laboratory which provides a unique opportunity to study biodiversity distribution (Lomolino et al., 2001), because the zonation of the mountain landscapes due to the 
elevational gradient. In Africa, the Mount Nimba chains located in the Guinean Forest of West Africa biodiversity hotspots, is considered as a priority area for conservation by its high degree of endemism and diversity. Unfortunately, the Mount Nimba Strict Nature Reserve (MNSNR), a Biosphere Reserve and World Heritage Site, located in the biodiversity hotspot, has its status compromised since 1992 (WHC, 2018). In fact, this transboundary Reserve between Guinea, Côte d'Ivoire and Liberia supports an exceptional variety of forest and savannah habitats. It also contains some of the highestgrade iron ores in the world. Consequently, this protected area undergoes pressures due to forest exploitation, poaching and mining activities which have already taken precedence in the Liberian sector (Bene et al., 2013). Despite these pressures, many taxa have received little attention, specifically insects which may reflect trends in species richness and community composition more accurately than vertebrates (Samways et al., 2010; Kone et al., 2018). Among insects, ants are a diverse and highly abundant insect group which plays an important functional role in tropical ecosystems (Ilboudo-Tapsoba et al., 2011; Andersen, 2019). In this sense, they are widely used as bioindicators in monitoring and rehabilitation programs (Fernandes and Souza, 2018), and reflect the trend that the conservational status of an area may determine the number and identity of species inhabiting it (Santiago et al., 2018). Although, these insects have been successfully used as bioindicators of mine site rehabilitation (Jamison et al., 2016), little studies have documented their predictive abilities.

This work was conducted in the framework of an environmental and social impact study of mining project "Nimba Iron "conducted by the "Société des Minerais de Fer de Guinée (SMFG)". The general objective of the present work is to establish how ants could serve as biological indicators by considering soil and climatic variables in different vegetation zones of Mount Nimba Strict Nature Reserve, and thus, provides indications on rehabilitation success in mining sites after disturbances. Specifically, this study aimed at comparing ant richness and species composition following vegetation zones and environmental variables in Mining area and World Heritage Site.

\section{MATERIALS AND METHODS Study Sites}

The study was conducted within the Nimba Mountain chains in the South-east of Guinea (altitude $809-1576$ m). The study sites lie in Biosphere Reserve and World Heritage Site (WHS) of Mount Nimba Strict Nature Reserve $\quad\left(07^{\circ} 36^{\prime} 11^{\prime \prime} .448 \mathrm{~N}\right.$ to $008^{\circ} 23^{\prime} 27^{\prime}$ '.492W), and its declassified portion referred as Mining Areas (MA) since 1968 (Figure 1). Climate in the area is a subequatorial mountain type, with total annual precipitation averages of $2,800 \mathrm{~mm}$ and mean annual temperature fluctuating between $18{ }^{\circ} \mathrm{C}$ and $33{ }^{\circ} \mathrm{C}$. Twelve locations were sampled (Table S1), all representing the main vegetation zones commonly found in the area, namely highland meadows, altitudinal forests and transition savannah between them. Highland meadows are vegetation zones which cover the ridges of Nimba Mounts. It is grassy vegetation without trees or shrubs dominated by Loudetia kagerensis and composed of orophilic species (Polystachya $s p$ ), species of lowland areas and mountain species from the flora of the plains (Lamotte et al., 2003). Vegetation of this area relay on ferralitic soils with indurated layers and hard and consistent breastplate (Diallo, 2017). The altitudinal forests cover mountain slopes from valleys to ridges and dominated by Parinari excelsa, a vegetation type characteristic of the West African rocky massif. The altitudinal forests of Nimba Mountains relay on deep ferralitic soils with homogeneous layers. The transition savannah is herbaceous vegetation consisting of trees and shrubs found at the edges of altitudinal forest. These transition savannahs are supported by gravelly soils and contain species typical of deforested areas dominated by Setaria ckevalieri, Pieridium lanuginosum, Dissotis jacquesii and Harungana madagascariensis (Lamotte et al., 2003).

\section{Ant Sampling and Environmental Data}

Sampling was conducted between April and May 2017, along two 200 metres 
transects. Each transect included 20 sampling points separated by $10 \mathrm{~m}$ from each other. Ants were captured using pitfall and baiting traps method on the same transect (Underwood and Fisher, 2006). Pitfall traps were plastic beverage cups $(330 \mathrm{ml}$, depth 8 $\mathrm{cm}$, mouth diameter $7 \mathrm{~cm}$ ) filled with trapping fluid $\left(70^{\circ}\right.$ alcohol + few drops of glycerine) (Yeo, 2006). Pitfall traps were serviced 2 days after the placement. Baiting was tuna lures placed along transect at $5 \mathrm{~m}$ apart from the pitfall traps. All the samples collected were preserved in an individual Eppendorf minitube of $2 \mathrm{ml}$ filled with alcohol (96\%) and labelled before processing. Ants were identified into genus level and into morphospecies level using the key given by Fisher and Bolton (2016). Species were named using the following keys: Tetramorium (Bolton, 1980); Cataulacus and Cardiocondyla (Bolton, 1982); Monomorium (Bolton, 1987); Nylanderia (LaPolla et al., 2011) and Doctor Yeo ant collection. Identified specimens were deposited at the Lamto Ecology Research Station in Côte d'Ivoire. Environmental data comprised weather and soil variables. Weather data included air temperature $\left({ }^{\circ} \mathrm{C}\right)$ and relative humidity (\%). We collected weather data by installing iButton DS1923 data logger to record air temperature and relative humidity. We then summarized these data to obtain a mean temperature and relative humidity for each surveyed site. We also collected three soil random cores for each surveyed site and analysed the samples at the soil analysis laboratory of "Institut de Recherche Agronomique de Guinée (IRAG)" at Kindia, in Guinea. Soil samples analysis included $\mathrm{pH}$, apparent density $\left(\mathrm{g} . \mathrm{cm}^{-3}\right)$, organic matter content (\%).

\section{Data analysis}

For statistical analysis, data were pooled for the two traps on each transect. The number of occurrences (absence/presence) of species was used as a measure of abundance rather than the number of individuals. To evaluate the inventory reliability, sampling coverage was calculated as the ratio of observed species richness and expected species richness obtained using nonparametric Chao 2 estimator included in Estimates 9.1.0 (Colwell et al., 2013). Then, data were generated to construct species accumulation curves which are a plot of observed species richness and expected species richness against sampling points. Ant communities were then described and compared following: species richness $(S)$ which is not sensitive to abundance and gives disproportionate weight to rare species; Shannon diversity index $\left(H^{\prime}\right)$ and Evenness $(E)$ which weight each species according to its abundance and can be interpreted as the number of typical species in the community; and finally Simpson Dominance diversity index $(D)$ which can be interpreted as the very abundant or the dominant species in the community (Jost, 2006). One-way analysis of Variance (ANOVA), Friedman test and Wilcoxon test were used to study variation in species richness and abundance after checking the normal distribution of our data. F and Ttests were conducted for paired comparison of weather and soil variables among the surveyed areas of both study sites. Then a multiple linear regression was conducted to test the effect of these environmental variables on ant species richness and abundance, formerly log-transformed. To investigate change in ant species composition and turnover between vegetation zones of each study site, a non-metric multidimensional scaling (NMDS) was built to visualize variation in composition among the study area. Furthermore, Bray-Curtis index values were used to perform an analysis of similarity (ANOSIM) based on 999 permutations to compare the difference in ant species composition among vegetation zones from each study site. ANOSIM generates a $R$ statistic that indicates the degree of average dissimilarity between the assemblage being compared. Values close to 1 indicate distinct differences, whereas values close to 0 indicate high level of similarity in species composition. Statistical analyses were performed using PAST 3.1.0 (Hammer et al., 2001). 


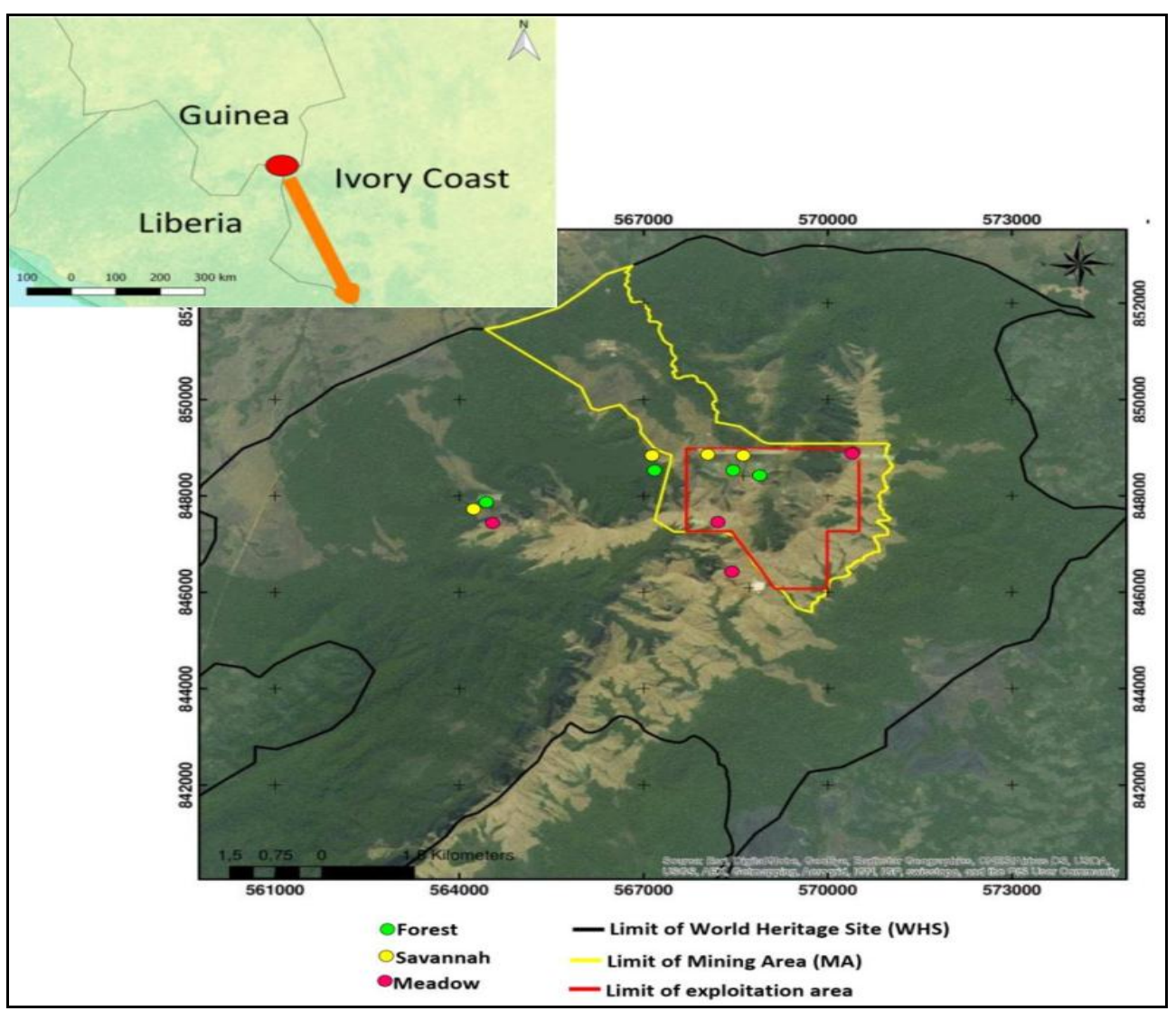

Figure 1: Location of study sites and sampling areas in vegetation of Guinean Nimba Mountain chains.

Table S1: Location and coordinates of study sites.

\begin{tabular}{|c|c|c|c|c|c|}
\hline Sites & Vegetation Zones & Sampling areas & Latitude & Longitude & Altitude \\
\hline \multirow{6}{*}{$\begin{array}{l}\text { World } \\
\text { Heritage Site }\end{array}$} & \multirow[b]{2}{*}{ Highland Forest } & Mt. Leclerc & N 0740’07.6” & W 08²5’01.1'” & 874 \\
\hline & & Mt. Gba valley & N 0740’34.1', & W 08²3'27.6’' & 1077 \\
\hline & \multirow[b]{2}{*}{ Savannah transition } & Mt. Leclerc & N 0740'14.7' & W 08²4'54.9'” & 809 \\
\hline & & Mt. Zougué & $\mathrm{N} 07^{\circ} 40^{\prime} 43.2^{\prime \prime}$ & 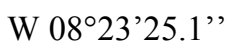 & 1122 \\
\hline & \multirow[b]{2}{*}{ Highland Meadow } & Mt. Leclerc & $\mathrm{N} 07^{\circ} 40^{\prime} 00.1^{\prime \prime}$ & W 08²4’44. $8^{\prime \prime}$ & 1140 \\
\hline & & Mt. Grand Rocher & N 07³9’23.1', & W 08²2’47.8'” & 1683 \\
\hline \multirow{6}{*}{ Mining Area } & \multirow[b]{2}{*}{ Highland Forest } & River Zié valley & N 0740’24.0' & W 08²2’21.6”' & 1273 \\
\hline & & Mt. Génie & N $07^{\circ} 40^{\prime} 48.8^{\prime \prime}$ & W 08²2'24.6”' & 1161 \\
\hline & \multirow[b]{2}{*}{ Savannah transition } & Mt. Château 1 & N 0740’35.4' & W 08²2’39.6”' & 1149 \\
\hline & & Mt. Château 2 & N 0740’42.4', & W 08²2'56.6”' & 1111 \\
\hline & \multirow[b]{2}{*}{ Highland Meadow } & Mt.Pierré Richaud & N 0740’43.6" & W 08²1'41.9'” & 1556 \\
\hline & & Mt. Sempéré & N 0740’03.5', & $\mathrm{W} 08^{\circ} 22^{\prime} 50.5^{\prime}$, & 1576 \\
\hline
\end{tabular}




\section{RESULTS}

The pitfalls and baiting traps have yielded 119 species and morphospecies for the whole study. Chao 2 estimator have predicted a maximum of 166 expected ant species collected with pitfall traps and baiting, thus, our sampling effort has shown that $71.1 \%$ of expected ant species was captured in both the study sites. However, we found that sampling coverage values were high for Meadow and Savannah, while low in forest areas (Table 1). The species accumulation curves continue to grow (Figure 2).

\section{Ant species diversity and richness}

In total, 95 ant species were recorded for the World Heritage Site and 69 species for the Mining area (ANOVA: $F=6.25, d f=5, p$ $<0.0001)$. The number of ant species collected was significantly different among vegetation zones in the World Heritage Site (ANOVA: $F=7.94, d f=2, p<0.0001$ ), while there was not a difference in Mining Area (ANOVA: $F=0.94, d f=2, \quad p=0.37$ ). In addition, observed species richness and Shannon's diversity index were high in forests and savannahs, whereas low values were noted in Meadows. However, Simpson's dominance index was relatively high in Meadows when compared with forests and savannahs (Table 1). Exceptionally, this metric was very low in the forests of World Heritage Site. Evenness values were ranged between 0.47 and 0.63 . The number of ant species richness differed significantly when comparing ant communities between vegetation zones for World Heritage Site and Mining areas (Friedman test: $X^{2}=14.17, d$ $f=5, p<0.0001$ ). Post-hoc pairwise comparison did not show a difference in the number of observed species richness among Meadows (Wilcoxon: $Z=1.33, p=0.182$ ). In contrast, a significant difference was noted between the observed species richness among forests $(\mathrm{Z}=$ $3.72, p<0.0001)$ and among savannahs $(Z=$ 2.03, $p=0.042)$. The comparison of the number of unique species detected showed that more species occurred in the forest and savannah habitats of World Heritage Site in contrary to Mining Area. As for Meadows few unique species occurred in this vegetation type (Table 1). Otherwise, except the $\mathrm{pH}(F=$ $8.35, d f=1, p=0.036)$, soil apparent density $(F=4.36, d f=1 \quad p=0.13)$, organic matter $(F=2.75, d f=1, p=0.29)$ and climatic variable temperature $(F=1.21, d f=1, p=0.83)$ and relative humidity $(F=2.12, d f=1, p=0.43)$ did not vary significantly when performing pairwise comparison among vegetation zones (Figure 3a, 3b). Likewise, the results have not shown any effect of weather and soil variables on ant species richness (ANOVA: $F=1.71 ; p$ $=0.26)$ and Abundance $(F=2.01 ; p=0.21)$.

\section{Species composition and Abundance}

Analysis of change in ant species composition showed that out of 119 ant species collected, World Heritage Site and Mining area shared 45 species. Ant species composition did not change significantly between both study site (ANOSIM: $R=-0.14$, $p=0.71$ ). However, the NMDS plot indicated that differences were more pronounced among forests, while an inverse trend was observed for Meadow and Savannah habitats (Figure 4). The pairwise comparison of vegetation zones revealed that Savannah habitats shared more ant species (22 species), followed by forest habitats with 18 shared species despite their high dissimilarity. As for the Meadows they shared 15 species (Table 2). In addition, this study recorded 1576 ants species occurrences representing 29 genera and 5 subfamilies. Myrmicinae was the most speciose subfamily, with 65 species followed by Formicinae (24 species), Ponerinae (16 species), Dorylinae ( 9 species) and Dolichoderinae (5 species) (Table 3). Ant abundance differed significantly among World Heritage Site and Mining Area (Friedman test: $X^{2}=16.51, d f=$ $5, \quad p<$ 0.0001). The Post-hoc pairwise comparison did not show a difference among the Meadows (Wilcoxon: $Z=0.06, p=0.95$ ), and among Savannah $(Z=1.33, p=0.182)$. Conversely, a difference was found among the Forest habitats $(Z=2.93, p=0.003)$. The most abundant species were Pheidole sp.14 with 134 occurrences (8.5\%) followed by Camponotus acvapimensis with 129 occurrences (8.2\%), Pheidole sp.13 with 97 
occurrences (6.15\%), Paltothyreus tarsatus with 79 occurrences $(5.01 \%)$ and Nylanderia scintilla with 71 occurrences $(4.5 \%$ ) (Table $3)$. Moreover, the study indicated that some ant species like Paltothyreus tarsatus occurred more in forests of Mining area and in all vegetation zones of World Heritage Site. Tetramorium brevispinosum occurred more in forests of Mining Area, while Technomyrmex andrei was common in forests of World Heritage Site. As for Meadows and
Savannahs, the most abundant species included Camponotus acvapimensis, Camponotus cinctellus, Lepisiota sp.7, Mesoponera caffraria, Nylanderia scintilla; Pheidole sp.20 and Polyrhachis schistacea. Exceptionally, Pheidole sp.14 was more abundant in the Meadow of World Heritage Site where the endemic viviparous toad Nimbaphrynoides occidentalis occurs at high abundance.

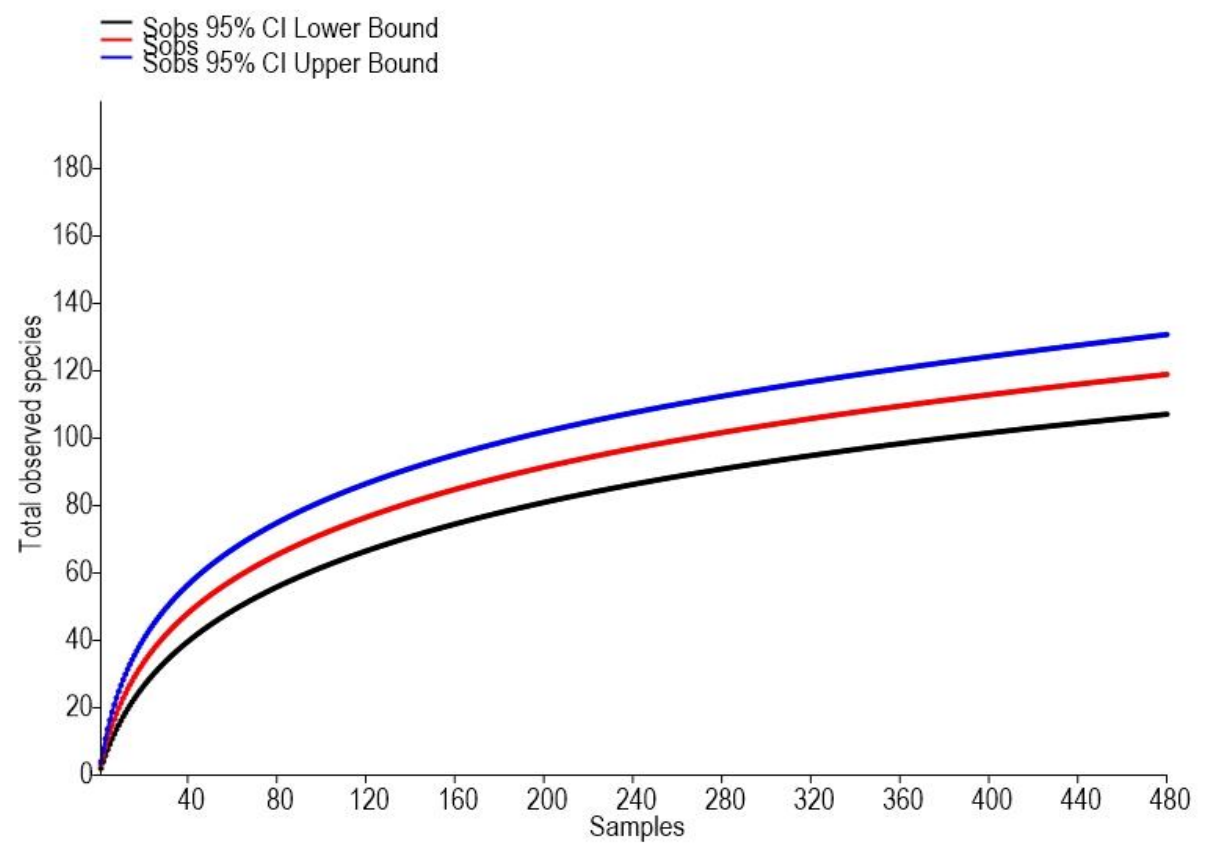

Figure 2: Species accumulation curves based on the total collection data set $(n=480)$ in both World Heritage Site and Mining area in the Mt. Nimba Strict Nature Reserve.

Table 1: Sampling coverage and diversity metrics of ant community in vegetation zones.

\begin{tabular}{lcccccc}
\cline { 2 - 7 } & \multicolumn{3}{c}{ World Heritage Site (WHS) } & \multicolumn{3}{c}{ Mining Area (MA) } \\
\cline { 2 - 7 } & Meadow & Forest & Savannah & Meadow & Forest & Savannah \\
\hline Sample coverage (\%) & 83 & 45 & 85 & 78 & 40 & 89 \\
Abundance (N) & 215 & 285 & 313 & 186 & 183 & 295 \\
Species richness (Sobs) & 27 & 56 & 48 & 25 & 33 & 33 \\
Chao 2 (Sest) & 32.53 & 125.13 & 56.56 & 31.91 & 81.39 & 36.95 \\
Simpson diversity (1/D) & 0.12 & 0.04 & 0.06 & 0.11 & 0.07 & 0.08 \\
Shannon diversity (H') & 2.54 & 4.02 & 3.87 & 2.76 & 3.50 & 3.50 \\
Evenness (E) & 0.47 & 0.59 & 0.51 & 0.63 & 0.57 & 0.53 \\
Unique species & 8 & 21 & 13 & 7 & 14 & 8 \\
\hline
\end{tabular}



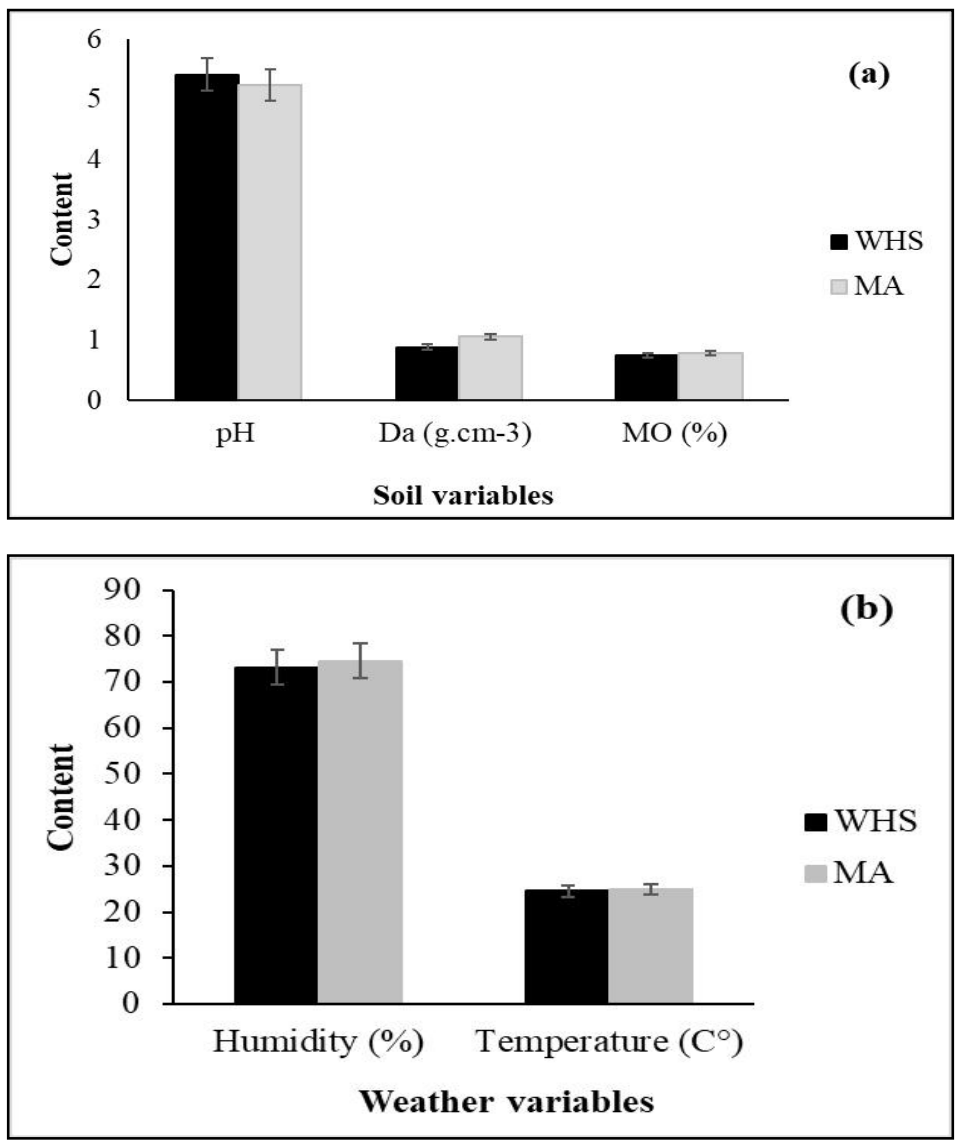

Figure 3: Soil and weather characteristics in two study sites: (a), $\mathrm{pH}(p=0.036)$, apparent density (Da) and soil organic matter (MO) (not significantly different); (b) Relative humidity and Temperature (not significantly different). WHS = World Heritage Site, MA = Mining Area.

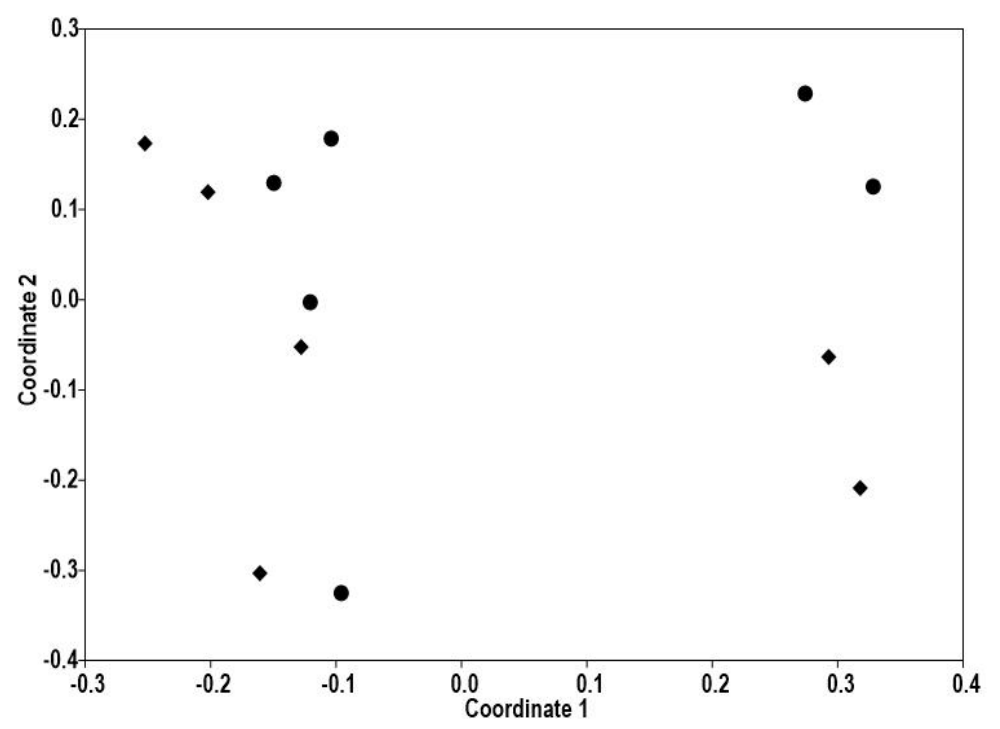

Figure 4: Ordination by non-metric multidimensional scale (NMDS) analysis showing the change in ant species composition among vegetation in the study sites (Axis $1=62,7 \%$; Axis $2=12,6 \%$; Stress $=0,11$. 
Table 2: Bray-Curtis similarity index (MA = Mining Area; WHS = World Heritage Site). The upper diagonal shows the number of ant species that occur in both vegetation zones.

\begin{tabular}{lcccccc}
\hline & $\begin{array}{c}\text { MA } \\
\text { Meadow }\end{array}$ & $\begin{array}{c}\text { MA } \\
\text { Savannah }\end{array}$ & $\begin{array}{c}\text { MA } \\
\text { Forest }\end{array}$ & $\begin{array}{c}\text { WHS } \\
\text { Meadow }\end{array}$ & $\begin{array}{c}\text { WHS } \\
\text { Savannah }\end{array}$ & $\begin{array}{c}\text { WHS } \\
\text { Forest }\end{array}$ \\
\hline MA Meadow & - & $\mathbf{1 4}$ & $\mathbf{5}$ & $\mathbf{1 5}$ & $\mathbf{1 6}$ & $\mathbf{8}$ \\
MA Savannah & 0.48 & - & $\mathbf{6}$ & $\mathbf{1 5}$ & $\mathbf{2 2}$ & $\mathbf{1 0}$ \\
MA Forest & 0.17 & 0.18 & - & $\mathbf{4}$ & $\mathbf{8}$ & $\mathbf{1 8}$ \\
WHS Meadow & 0.54 & 0.5 & 0.16 & - & $\mathbf{1 9}$ & $\mathbf{1 2}$ \\
WHS Savannah & 0.44 & 0.54 & 0.20 & 0.53 & - & $\mathbf{1 4}$ \\
WHS Forest & 0.20 & 0.22 & 0.43 & 0.28 & 0.27 & - \\
\hline
\end{tabular}

Table 3: Abundance (occurrences) of ant species according to different vegetation type in World Heritage Site and Mining Area.

Mining Area World Heritage

Site

\begin{tabular}{|c|c|c|c|c|c|c|}
\hline Species & Mw & Sh & $\mathbf{F t}$ & Mw & Sh & $\mathbf{F t}$ \\
\hline Aenictus sp.1(D) & 0 & 0 & 0 & 0 & 0 & 1 \\
\hline Aenictus sp.2 (D) & 0 & 0 & 0 & 0 & 0 & 1 \\
\hline Aenictus sp.3 (D) & 0 & 0 & 0 & 0 & 0 & 1 \\
\hline Aenictus sp.4 (D) & 0 & 0 & 0 & 0 & 1 & 0 \\
\hline Anochetus africanus Mayr, 1865 (P) & 0 & 0 & 0 & 0 & 0 & 3 \\
\hline Anochetus sp.2 (P) & 0 & 0 & 0 & 0 & 0 & 1 \\
\hline Anochetus sp.3 (P) & 0 & 0 & 0 & 0 & 0 & 6 \\
\hline Anochetus sp.4 (P) & 0 & 3 & 0 & 0 & 0 & 0 \\
\hline Bothroponera soror Emery, 1899 (P) & 23 & 0 & 0 & 4 & 2 & 3 \\
\hline Calyptomyrmex nummuliticus Santschi, 1914 (M) & 0 & 0 & 0 & 0 & 1 & 0 \\
\hline Camponotus acvapimensis Mayr, $1862(\mathrm{~F})$ & 19 & 45 & 0 & 19 & 46 & 0 \\
\hline Camponotus cinctellus Gerstäcker, 1859 (F) & 6 & 17 & 0 & 0 & 11 & 0 \\
\hline Camponotus compressiscapus Andre, 1889(F) & 0 & 2 & 0 & 0 & 1 & 0 \\
\hline Camponotus maculatus Fabricius, 1782 (F) & 0 & 2 & 3 & 0 & 7 & 10 \\
\hline Camponotus osiris Forel, 1911(F) & 3 & 6 & 0 & 1 & 5 & 0 \\
\hline Camponotus puberulus $(\mathrm{F})$ & 0 & 3 & 0 & 0 & 0 & 0 \\
\hline Camponotus sp.1 (F) & 0 & 0 & 5 & 0 & 0 & 0 \\
\hline Cardiocondyla neferka Bolton, 1982 (M) & 0 & 0 & 0 & 2 & 0 & 0 \\
\hline Carebara sp.5 (M) & 0 & 0 & 0 & 0 & 1 & 7 \\
\hline Carebara sp.6 (M) & 0 & 0 & 0 & 0 & 0 & 3 \\
\hline Carebara Lilith (M) & 0 & 0 & 0 & 0 & 0 & 1 \\
\hline Carebara villersi (M) & 0 & 0 & 0 & 0 & 0 & 3 \\
\hline Carebara distincta Bolton \& Belshaw, 1993 (M) & 0 & 0 & 0 & 0 & 0 & 5 \\
\hline
\end{tabular}


Carebara silvestrii Santschi, 1914 (M)

Parasyscia nitidulus Brown, 1975 (D)

$\begin{array}{cccccc}0 & 0 & 1 & 0 & 1 & 1 \\ 0 & 0 & 0 & 0 & 0 & 1 \\ 0 & 0 & 0 & 0 & 0 & 1 \\ 0 & 1 & 0 & 0 & 0 & 0 \\ 0 & 0 & 2 & 0 & 0 & 0 \\ 0 & 9 & 0 & 3 & 22 & 0 \\ 0 & 0 & 0 & 0 & 3 & 0 \\ 0 & 0 & 0 & 0 & 0 & 1 \\ 0 & 0 & 14 & 0 & 2 & 9 \\ 0 & 0 & 0 & 0 & 0 & 2 \\ 0 & 0 & 1 & 0 & 0 & 0 \\ 0 & 0 & 0 & 2 & 0 & 0 \\ 0 & 0 & 0 & 0 & 0 & 1 \\ 0 & 0 & 1 & 0 & 0 & 0 \\ 0 & 0 & 0 & 0 & 0 & 1 \\ 0 & 0 & 0 & 0 & 2 & 0 \\ 0 & 1 & 0 & 0 & 0 & 0 \\ 0 & 0 & 0 & 2 & 2 & 0 \\ 0 & 4 & 0 & 0 & 0 & 0 \\ 0 & 0 & 0 & 4 & 0 & 0 \\ 0 & 0 & 0 & 0 & 16 & 3 \\ 0 & 40 & 0 & 5 & 4 & 1 \\ 0 & 0 & 0 & 1 & 1 & 0 \\ 6 & 0 & 0 & 0 & 0 & 0 \\ 2 & 0 & 0 & 0 & 0 & 0 \\ 0 & 0 & 0 & 0 & 2 & 0 \\ 0 & 0 & 0 & 10 & 0 & 0 \\ 0 & 0 & 0 & 0 & 0 & 1 \\ 2 & 1 & 0 & 0 & 1 & 1 \\ 0 & 2 & 0 & 0 & 4 & 0 \\ 0 & 0 & 0 & 0 & 3 & 0 \\ 1 & 20 & 0 & 8 & 21 & 8 \\ 1 & 0 & 0 & 0 & 3 & 0 \\ 0 & 2 & 0 & 5 & 6 & 0 \\ 0 & 0 & 0 & 0 & 0 & 2 \\ 0 & 0 & 0 & 0 & 16 & 0 \\ 0 & 0 & 0 & 2 & 0 & 1 \\ 0 & 1 & 0 & 12 & 0 & 0\end{array}$

Parasyscia sp.1 (D)

Crematogaster sp.10 (M)

Crematogaster sp.13 (M)

Crematogaster sp.16 (M)

Crematogaster sp.17 (M)

Crematogaster sp.21 (M)

Crematogaster striatula Emery, 1892 (M)

Dorylus sp.3 (D)

Dorylus sp.4 (D)

Dorylus sp.5 (D)

Hypoponera dulcis Forel, 1907 (P)

Hypoponera punctatissima Roger, 1859 (P)

Hypoponera sinuosa Bernard, 1953 (P)

Hypoponera sp.1 (P)

Hypoponera sp.2 (P)

Lepisiota sp.2 (F)

Lepisiota sp.3 (F)

Lepisiota sp.5 (F)

Lepisiota sp.6 (F)

Lepisiota sp.7 (F)

Lepisiota sp.8 (F)

Lepisiota sp.9 $(\mathrm{F})$

Lepisiota sp.10 (F)

Lepisiota sp.11 (F)

Lepisiota sp.12 (F)

Lepisiota sp.13 (F)

Leptogenys Ferrari Forel, 1913 (P)

Meranoplus inermis Emery, 1895 (M)

Meranoplus amaretti Andre, 1884 (M)

Mesoponera caffraria Smith, 1858 (P)

Monomorium bicolor Emery, 1877 (M)

Monomorium dictator Santschi, 1937 (M)

Monomorium invidium Bolton, 1987 (M)

Monomorium occidentale Bernard, 1953 (M)

Monomorium rosae Santschi, 1920 (M)

Monomorium sp.1 (M)

Monomorium sp.2 (M)

Nylanderia boltoni LaPolla, Hawkes \& Fisher, 2011 (F) 
Nylanderia lepida (Santschi, 1915) (F)

Nylanderia scintilla LaPolla, Hawkes \& Fisher, 2011 (F)

Odontomachus assiniensis Emery, 1892 (P)

Oecophylla longinoda (Latreille, 1802) (F)

Paltothyreus tarsatus Fabricius, 1798 (P)

Parparatrechina sp.1 (F)

Pheidole buchholzi Mayr, 1901 (M)

Pheidole pulchella Santschi, 1910 (M)

Pheidole sp.2 (M)

Pheidole sp.4 (M)

Pheidole sp.8 (M)

Pheidole sp.9 (M)

Pheidole sp.10 (M)

Pheidole sp.11 (M)

Pheidole sp.13 (M)

Pheidole sp.14 (M)

Pheidole sp.16 (M)

Pheidole sp.17 (M)

Pheidole sp.18 (M)

Pheidole sp.19 (M)

Pheidole sp.20 (M)

Pheidole sp.21 (M)

Pheidole sp.22 (M)

Phrynoponera gabonensis Andre, 1892 (P)

Polyrhachis militaris Fabricius, 1782 (F)

Polyrhachis schistacea Gerstäcker, 1859 (F)

Pseudolasius sp.1 (F)

Solenopsis sp.1 (M)

Solenopsis sp.2 (M)

Strumigenys ludovici Forel, 1904 (M)

Strumigenys nimbrata Bolton, 1983 (M)

Strumigenys ninda Bolton, 1983 (M)

Strumigenys rukha Bolton, 1983 (M)

Technomyrmex andrei Emery, 1899 (Dl)

Technomyrmex morens Santschi 1913 (Dl)

Technomyrmex sp.2 (Dl)

Technomyrmex sp.3 (Dl)

Technomyrmex voeltzkowi Forel 1907 (Dl)

Tetramorium aculeatum Mayr, 1866 (M)

Tetramorium anxium (Santschi, 1914) (M)

$\begin{array}{cccccc}0 & 0 & 10 & 0 & 0 & 5 \\ 21 & 4 & 0 & 36 & 10 & 0 \\ 0 & 0 & 10 & 0 & 0 & 1 \\ 0 & 0 & 0 & 0 & 0 & 4 \\ 0 & 2 & 18 & 15 & 15 & 29 \\ 0 & 0 & 0 & 0 & 0 & 6 \\ 0 & 0 & 4 & 0 & 0 & 1 \\ 0 & 0 & 3 & 0 & 0 & 11 \\ 0 & 0 & 0 & 0 & 1 & 0 \\ 0 & 0 & 0 & 1 & 16 & 0 \\ 1 & 10 & 0 & 0 & 0 & 0 \\ 6 & 39 & 1 & 0 & 0 & 0 \\ 14 & 14 & 13 & 4 & 3 & 1 \\ 0 & 1 & 6 & 0 & 5 & 9 \\ 25 & 0 & 28 & 41 & 0 & 3 \\ 16 & 11 & 6 & 94 & 7 & 0 \\ 0 & 0 & 5 & 0 & 0 & 6 \\ 0 & 0 & 1 & 0 & 0 & 0 \\ 0 & 0 & 3 & 0 & 0 & 0 \\ 0 & 0 & 0 & 0 & 1 & 0 \\ 0 & 12 & 0 & 2 & 31 & 9 \\ 0 & 0 & 1 & 0 & 0 & 27 \\ 0 & 0 & 0 & 0 & 0 & 1 \\ 0 & 0 & 1 & 0 & 0 & 6 \\ 0 & 0 & 0 & 0 & 0 & 5 \\ 9 & 17 & 0 & 1 & 11 & 0 \\ 0 & 0 & 0 & 0 & 3 & 0 \\ 0 & 0 & 0 & 0 & 1 & 0 \\ 7 & 0 & 0 & 0 & 0 & 0 \\ 0 & 0 & 1 & 0 & 0 & 0 \\ 0 & 0 & 0 & 0 & 1 & 0 \\ 0 & 1 & 0 & 0 & 1 & 0 \\ 0 & 0 & 0 & 0 & 1 & 0 \\ 0 & 0 & 5 & 0 & 0 & 29 \\ 0 & 0 & 0 & 0 & 0 & 1 \\ 0 & 0 & 0 & 1 & 0 & 3 \\ 0 & 1 & 0 & 0 & 0 & 0 \\ 0 & 2 & 0 & 0 & 0 & 0 \\ 0 & 0 & 1 & 0 & 0 & 0 \\ & 2 & 0 & 1 & 2 & 0 \\ & & & & \end{array}$


Tetramorium ataxium Bolton, 1980 (M)

Tetramorium brevispinosum Stitz, 1910 (M)

Tetramorium delagoense Forel, 1894 (M)

Tetramorium distinctum Bolton, 1976 (M)

Tetramorium edouardi Forel, 1894 (M)

Tetramorium flavithorax Santschi, 1914 (M)

Tetramorium furtivum Arnold, 1956 (M)

Tetramorium gracile Forel, 1894 (M)

Tetramorium guineense Bolton, 1980 (M)

$\begin{array}{cccccc}0 & 6 & 0 & 0 & 3 & 0 \\ 0 & 0 & 30 & 0 & 0 & 4 \\ 0 & 0 & 0 & 0 & 0 & 6 \\ 0 & 0 & 0 & 0 & 0 & 1 \\ 0 & 0 & 7 & 0 & 4 & 0 \\ 0 & 0 & 1 & 0 & 0 & 5 \\ 6 & 12 & 0 & 1 & 0 & 6 \\ 0 & 0 & 1 & 0 & 0 & 0 \\ 6 & 0 & 17 & 0 & 0 & 14 \\ 1 & 2 & 0 & 1 & 2 & 5 \\ 0 & 0 & 0 & 0 & 0 & 5 \\ 0 & 0 & 1 & 0 & 0 & 0 \\ 1 & 0 & 0 & 0 & 0 & 0 \\ 1 & 0 & 0 & 1 & 2 & 0 \\ 0 & 0 & 1 & 0 & 0 & 0 \\ 1 & 0 & 0 & 7 & 4 & 0\end{array}$

Tetramorium intonsum Bolton, 1980 (M)

Tetramorium invictum Bolton, 1980 (M)

Tetramorium kestrum Bolton, 1980 (M)

Tetramorium minimum Bolton, 1976 (M)

Tetramorium muralti Forel, 1910 (M)

Tetramorium pylacum Bolton, 1980 (M)

Tetramorium sericeiventre Emery, 1877 (M)

(D1): Dolichoderinae, (D): Dorylinae, (F): Formicinae, (M): Myrmicinae, (P): Ponerinae; Mw: Meadow, Sh: Savannah,

Ft: Forest.

\section{DISCUSSION}

This study uses ant communities of distinct vegetation zones to provide indications on the environmental conditions in a mining area located at the core of Mount Nimba Strict Nature Reserve. Because ants are sensitive to the disturbance process (Andersen et al., 2006; Vasconcelos et al., 2000), we used these insects as biological indicators in sight to forecast the possible success of habitat rehabilitation after mining activities. Even with limited sampling, this study enabled to collect more of the half of expected species with pitfall traps and baiting ( sample coverage $=71.1 \%$ ), and so, showed that sampling was representative of surveyed ant community. However, species accumulation curves failed to reach an asymptotic allure, implying that additional sampling was required to fit the pool of local species richness (Koné, 2013), specifically for forest habitats. It is important to mention that the low value of sampling coverage in forest habitats may be explained by trapping methods used here. In fact, pitfall and bait trapping are not only enough for sampling in the forest because these methods do not collect leaf-litter ant efficiently (Underwood and Fisher, 2006). The sampling coverage will have to be probably different if ant communities associated to leaf litter have been sampled. However, the needs to conduct additional sampling does not invalidate the data of this study, as the sample coverage indicates a good sampling effort.

In this study, ant species richness varied strongly, both among study sites and among vegetation zones. That may be explained by the level of disturbance between surveyed sites. The decreasing of species richness along a gradient of disturbance is common in tropical areas (Yeo et al., 2011, Garcia-Martinez et al., 2017). In fact, the Mining area is strongly subject to continue prospecting activities, implying a high level of human-induced disturbance in comparison to the protected area of World Heritage Site. These disturbances may have reduced the ant species richness by changing habitat structure or microclimate and resource availability as reported in other studies (Ribas et al., 2012; Arnillas et al., 2017). Another possible 
explanation could be the influence of vegetational formation or latitudinal gradients on the structure of the ant community (Silva et al., 2017; Vasconcelos et al., 2018). It is the case in this study, where, even though the objective was not focused on how latitudinal gradient affect ant species richness, a notable difference of ant species richness was recorded when the Meadow, Forest and Savannah habitats were compared. The value of Shannon diversity index reinforces the pattern observed with Species richness. However, the high value of Simpson dominance index in Meadow habitats may be due to the high abundance of some ant species compared to other. This finding is consistent with those of other studies documenting arthropods diversity in Alpine meadows (Maveety et al., 2013; Hiramatsu and Usio, 2018).

In contrast to the pattern observed with species richness, the comparison of species composition indicated a similar ant assemblage between World Heritage Site and Mining area. This pattern of similarity, albeit not extremely high, could indicate that both World Heritage Site and Mining Area have similar habitat features. This observation is reinforced by the fair resemblance of ant species composition as indicated by NMDS. Conversely, the dissimilarity of ant species composition among forest was more slightly pronounced when comparing this habitat for both study sites. This finding may suggest that ant assemblage of forest habitats could be more sensitive to mining prospecting activities than Meadow and Savannah habitats.

Interestingly, this study showed that the taxonomic structure of ant community of both study sites was dominated by Myrmicinae, followed by Formicinae and Ponerinae. Dolichoderinae and Dorylinae were less abundant in this study. The high abundance of Myrmicinae may be due the biology of the species belonging to this subfamily. As reported by Koné (2013), the Myrmicinae are widely distributed because of their biology which facilitates their resistance to environmental disturbances and their generalist attributes which favour their prevalence in all habitats. In addition, with the observed pattern in abundance and the absence of effect of measured environmental variables on ant species richness and abundance, the findings of this study may support the hypothesis of species composition responds to vegetation zonation. These finding are consistent with those of Wenninger and Inouye (2008) and Cardoso et al., (2010) who reported that changes in the structure of vegetation result in changes of composition of organisms living there. In addition, this study indicated that many ant species, namely Pheidole sp.14, Camponotus acvapimensis, Pheidole sp.13, Paltothyreus tarsatus and Nylanderia scintilla were more prevalent within the vegetation zones of the study sites. Amongst these species, several were more typical (i.e. found at higher occurrences) of a given vegetation zone when considering their occurrences. For instance, Paltothyreus tarsatus occurred more in forest habitats of Mining area and in all vegetation zones of World Heritage Site. This species belonging to Ponerinae is a predator generalist, sensitive to disturbances which lead the lack of nourishment throughout the lack prey diversity (Kone, 2013). Its occurrence in all habitats of World Heritage Site could indicate a good conservation state of this area. Other species like Tetramorium brevispinosum occurred more in forests of Mining Area, while Technomyrmex andrei was common in forests of World Heritage Site. As for Meadows and Savannahs, species adapted to open areas like Camponotus acvapimensis, Camponotus cinctellus, Lepisiota sp.7, Mesoponera caffraria, Nylanderia scintilla; Pheidole sp.20 and Polyrhachis schistacea, were more common.

\section{Conclusion}

This study shown evidence that the ant species diversity, richness and abundance were impacted by mining prospecting activities independently of soil and climatic variables. Likewise, when considering the assemblage of ant species across vegetation zones and the bioindicator capacity of these insects, the forest habitats in mining area 
could be more impacted by mining activities rather than Meadows and transition Savannahs. Rehabilitation action should be focused on the protection and rehabilitation of native forest. Finally, although this study provides relevant conclusion on the possible impact of mining activities on ant community and certainly on all other components of biodiversity, the time devoted to the sampling was short. We suggest a continue monitoring using ant and other taxonomic groups in order to develop more environmental planning instruments for rehabilitation actions.

\section{COMPETING INTERESTS}

The authors declare that they have no competing interests.

\section{AUTHORS' CONTRIBUTIONS}

Conceptualization: KY. Investigation, writing original draft: KY, LMMK and MKTEG. Specimens' identification: LMMK, KO and ANS. Writing, review and editing: KY, LMMK, MKTEG, KO and ANS.

\section{ACKNOWLEDGEMENTS}

We are grateful to the reviewers which the positive suggestions greatly improved the quality of this paper. We also thank Blaise Pivi, François Gbemou, Aboubacar Samoura, Nounke Kanté, Hassane Diallo and Dr Martinez Arnauth Guei for their technical assistance during the fieldwork.

\section{REFERENCES}

Andersen AN, Hertog T, Woinarski JCZ. 2006. Long-term fire exclusion and ant community structure in an Australian tropical savannah: congruence with vegetation succession. J. Biogeogr., 33(5): 823-832. DOI: https://doi.org/10.1111/j.1365-

2699.2006.01463.x.

Andersen AN. 2019. Responses of ant communities to disturbance: Five principles for understanding the disturbance dynamics of a globally dominant faunal group. J. Animal Ecology, 88(3): $\quad 350-362 . \quad$ DOI : https://doi.org/10.1111/1365-

2656.12907.

Arnillas CA, Tovar C, Cadotte MW, Buytaert W. 2017. From patches to richness: assessing the potential impact of landscape transformation on biodiversity. Ecosphere, 8(11): e02004. DOI: $10.1002 /$ ecs02004

Bene JCK, Gamys J, Dufour S. 2013. A wealth of Wildlife Endangered in northern Nimba County, Liberia. Inter. J. Innov. Appl. Studies, 2(3): 314-323.

Bolton B. 1980. The ant tribe Tetramoriini (Hymenoptera: Formicidae). The genus Tetramorium Mayr in the Ethiopian zoogeographical region. Bulletin of the British Museum (Natural History) Entomology, 40(3):193-384.

Bolton B. 1982. Afrotopical species of the myrmicine Cardiocondyla, Leptothorax, Melissotarsus, Messor and Cataulacus (Formicidae) in the Ethiopian region. Bulletin of the British Museum (Natural History) Entomology, 45(4):307-370

Bolton B. 1987. A review of the Solenopsis genus-group and revision of Afrotropical Monomorium Mayr (Hymenoptera: Formicidae). Bulletin of the British Museum (Natural History) Entomology, 54(3): 263-452.

Cardoso DC, Sobrinho TG, Schoereder JH. 2010. Ant community composition and its relationship with phytophysiognomies in a Brazilian Restinga. Insectes Sociaux, 57(3): 293-301. DOI: 10.1007/s00040010-0084-3

Colwell RK. 2013. Estimates: statistical estimation of species richness and shared species from simples, version 9.0. http://purl. oclc. org/estimates.

Diallo H. 2017. Rapport de prospections pédologiques et d'Analyse d'échantillon de sols. Rapport de l'Institut de Recherche Agronomique de Guinée pour la Société des Mines de Fer de Guinée, Kindia- Guinée, 23 p.

Fernandes I, de Souza J. 2018. Dataset of long-term monitoring of grounddwelling ants (Hymenoptera: Formicidae) in the influence areas of a 
hydroelectric power plant on the Madeira River in the Amazon Basin. Biodiver. Data J., 6: e24375. DOI: 10.3897/BDJ.6. e24375

Fisher BL, Bolton B. 2016. Ants of Africa and Madagascar: A Guide to the Genera. University of California Press, Oakland, California.

Garcia-Martınez MA, Valenzuela-Gonzalez JE, Escobar-Sarria F, Lopez-Barrera F, Castaño-Meneses G. 2017. The surrounding landscape influences the diversity of leaf-litter ants in riparian cloud forest remnants. PLOS ONE., 12(2): e0172464. DOI: 10.1371/journal.pone.0172464

Gaston KJ, Spicer JI. 2004. Biodiversity: an introduction. Blackwell Publishing.

Hammer Ø, Harper DAT, Rian PD. 2001. PAST: paleontological statistic software package for education and data analysis. Palaeontol. Electron., 4(1): 1-9.

Hiramatsu S, Usio N. 2018. Assemblage Characteristics and Habitat Specificity of Carabid Beetles in a Japanese AlpineSubalpine Zone. Psyche., 2018: 1-15. DOI: https://doi.org/10.1155/2018/9754376

Ilboudo-Tapsoba E, Tankoano H, Ouedraogo M, Dicko IO, Sanon A. 2011. Diversité des insectes actifs au sol dans quatre écosystèmes de bas-fonds du Burkina Faso : importance pour la détermination de bio-indicateurs caractérisant ces milieux. International Journal of Biological and Chemical Sciences, 5(2): 724-738.

Jamison SL, Robertson M, Engelbrecht I, Hawkes P. 2016. An assessment of rehabilitation success in an African grassland using ants as bioindicators. Koedoe African Protected Area Conservation and Science., 58(1):1-16. DOI: htp://dx.doi. org/10.4102/koedoe. v58i1.1383

Jost L. 2006. Entropy and diversity. Oikos., 113(2): 363-375. DOI: https://doi.org/10.1111/j.2006.00301299.14714.x
Kone M, Tuo Y, Yapo ML, Soro YA, Dosso N, Kambou B. 2018. Pratiques culturales et diversité des insectes en cultures vivrières à Korhogo (Nord, Côte d'Ivoire). International Journal of Biological and Chemical Sciences, 12(6): 2644-2652. DOI: https://dx.doi.org/10.4314/ijbcs.v12i6.14

Koné M. 2013. Effets de l'intensification des modes d'utilisation des terres et du gradient d'age de la cacaoculture sur la diversité biologique des fourmis en zones préforestière (lamto) et forestière semidécidue (Oumé) de Côte d'Ivoire. Thèse de l'Université Felix Houphouet Boigny, Abidjan, Côte d'Ivoire, p.177.

Lamotte M, Rougerie G, Roy R, Schnell R. 2003. Le Nimba et ses principaux biotopes, in Lamotte M, Roy R (Ed). Le peuplement animal du mont Nimba (Guinée, Côte d'Ivoire, Liberia). Mémoires du Muséum national d'Histoire naturelle, 190: 29-50.

LaPolla JS, Hawkes PG, Fisher BL. 2011. Monograph of Nylanderia (Hymenoptera: Formicidae) of the world, part I: Nylanderia in the Afrotropics. Zootaxa., 3110: 10-36. DOI: 10.5281/zenodo. 279290

Lomolino MV. 2001. Elevational gradients of species-density: historical and prospective views. Global Ecol. Biogeogr. 10: 3-13. DOI: 10.1046/j.1466-822x.2001.00229. x.

Maveety SA, Browne RA, Erwin TL. 2013. Carabid beetle diversity and community composition as related to altitude and seasonality in Andean forests. Studies on Neotropical Fauna and Environment, 48(3): $\quad 1-10 . \quad$ DOI: http://dx.doi.org/10.1080/01650521.2013 .873266

Ribas CR, Campos RBF, Schmidt FA, Solar RRC. 2012. Ants as indicators in Brazil: A review with suggestions to improve the use of ants in environmental monitoring programs. Psyche., 2012: 123. DOI: $10.1155 / 2012 / 636749$

Samways MJ, McGeoch MA, New TR. 2010. Insect conservation: a handbook of 
approaches and methods. Oxford University Press, Oxford.

Santiago GS, Campos RBF, Ribas CR. 2018. How does landscape anthropizaton affect the myrmecofauna of urban forest fragments? Sociobiology, 65(3): 441448. DOI: 10.13102/sociobiology. v65i3.3042

Silva RR, Feitosa RSM, Eberhardt F. 2007. Reduced ant diversity along a habitat regeneration gradient in the southern Brazilian Atlantic Forest. For. Ecol. Manag., 240(13): 61-69. DOI: https://doi.org/10.1016/j. foreco.2006.12.002

Underwood EC, Fisher BL. 2006. The role of ants in conservation monitoring: if, when, and how. Biol. Conser., 132(2): 166-182.

DOI: 10.1016/j.biocon.2006.03.022.

Vasconcelos HL, Maravalhas JB, Feitosa RM, PachecoR, Neves KC, Andersen AN. 2018. Neotropical savannah ants show a reversed latitudinal gradient of species richness, with climatic drivers reflecting the forest origin of the fauna. $J$. Biogeogr., 245(1): 248-258. DOI: 10.1111/jbi.13113

Vasconcelos HL, Vilhena JMS, Caliri GJA. 2000. Responses of ants to selective logging of a central Amazonian forest. $J$. Appl. Eco., 37(3): 508-514. DOI: https://doi.org/10.1046/j.1365-

2664.2000.00512.x

Wenninger EJ, Inouye RS. 2008. Insect community response to plant diversity and productivity in a sagebrush-steppe ecosystem. J. Arid. Env., 72(1): 24-33. DOI:

https://doi.org/10.1016/j.jaridenv.2007.0 4.005 .

WHC: World Heritage Comminttee. 2018. Convention concerning the protection of the World Cutural and Natural Heritage. Report WHC/18/42.com/7a.add, Accessed October $\quad 3^{\text {rd }}, 2018$. http://whc.unesco.org/en/sessions/42CO $\mathrm{M} /$ documents.

Yeo K, Konate S, Tiho S, Camara SK. 2011. Impacts of land use zones on ant communities in a tropical forest margin (Oumé - Côte d'Ivoire). Afr. J. Agr. Res., 6(2): 260-274. DOI: 10.5897/AJAR09.479

Yeo K. 2006. Dynamique spatiale et diversité des fourmis de la litière et du sol dans une mosaïque foret-savane en Côte d'ivoire. Thèse de Doctorat en cotutelle de l'Université Pierre Marie Curie et Université d'Abobo Adjamé. p.212. 